\title{
Societal Perception of Repositioning Childhood Education through Mother Tongue: Prospects and Challenges in Northwest Nigeria
}

\author{
Sarkinfada Halima (Ph.D) \\ Usmanu Danfodiyo University Sokoto
}

\begin{abstract}
This paper focuses on prospects and problems of the use of mother tongue as medium of instruction for the whole duration of primary education in the North Western States of Nigeria. The language of instruction is very crucial to education at every level because it serves as the key to learning. Mother tongue serves as the first language of children. Low trend of enrolment in primary school has been attributed to the use of foreign language of instruction in schools which is contrary to the customs and traditions of the people in the North Western states of Nigeria. Pupils find it difficult to socialize with the English language and do not have a sense of belonging in school. The research intends to examine the prospects and problems of the use of mother tongue as a medium of instruction for pupils in North west Nigeria. The study adopted descriptive survey design. The instrument for this study was a self-develop questionnaire titled "Questionnaire on prospects and problems Mother tongue". The population of the study include stakeholders' in the society, which include parents, Guardians, and Teachers, involved in childhood education. A total of 907 participated in the study, 113 parents, 30 Guardian, and 764 Teachers, Stratified sampling technique was used to select 3 States from 7 North-western states. Which include Katsina, Kebbi, and Sokoto states in North West Nigeria.. Ten (10) metropolitan primary schools were selected from the 3 states using simple random sampling technique. Since there no significant difference between the views of parents, teachers and other stakeholders on the prospects of the use of mother tongue as a medium of instruction for pupils in North West Nigeria. It is therefore recommended that since the prospects of Mother tongue ate inevitable and its challenges are inherent. Teachers, parents and all stakeholders should be more proactive in discharging their professional functions in teaching of Mother Tongue and the English language currently during lessons.
\end{abstract}

Key word: Mother tongue Prospects and Challenges

\section{Introduction}

Language is a means of self-expression and exchange of ideas through which we communicate with others by mean of work oral and written. Language is the expression of thought and emotions in oral or written form. Bhatia (2006) explained that mother tongue is the language that a child learns or imbibes from his mother. It is the language which the child learns almost without any conscious effort on his/her part. It is also language which the child learns in the lap of his mother and acquires while living in his own social group. Mother tongue plays a tremendously useful role in the education of a child. Therefore, mother tongue must be given an important and prominent place in the school curriculum, It must be stated, however, that in the recent past, mother tongue as a language of instruction was given its place in the school curriculum.
The importance of mother tongue was not even partially recognized in the sphere of education. The reasons English came to have dominant place on Nigeria. Mother tongue has been acknowledge as the best medium for the expression of one's ideas and feelings, as $t$ is the most potent agent for mutual communication and exchange of ideas. An individual can express himself most easily and lucidly in his/her own mother tongue. The formation of social group is through language and specially through the mother tongue, that individual form themselves into social organization. The very existence of a society is due to the native language or the mother tongue. Easy to learn, of all the languages, mother tongue proficiency or mastery can be achieved in one's own mother tongue. UNESCO (2003) explained that the best medium for acquiring knowledge is language, and it is 
impossible to acquire knowledge without language, thought knowledge and language are inextricable linked together, it is also instrument of creative self expression, it is an instrument for emotional development and instrument for growth of the pupils. The prospects of mother tongue is to give command of language, that is to give the child a good command of their mother tongue that they can speak easily and clearly what they want to say, and simply write. In other words mother tongue teaches them to express themselves clearly without hinge or misunderstanding. Another important prospect is to teach the pupils to read for information and for pleasure, to introduce him gradually to the joys of great prose and poetry, and to show him what store of information there is in books. To cultivate in him the habit of reading for the acquisition of knowledge; To bring about the mental and emotional development, pupils express their feelings, thought and experiences, so that they may have the great satisfaction that such expression grave, and may have the chance if the mental and moral development for which such expression is essential; To develop creative faculties of the pupils is of the most significant aims of teaching mother tongue. The pupil has in his mother tongue a medium through which he can give expression, in different directions, to the creative urge that is in him; To give training in logical thought and expression. (Bhatia, 2006)

The National Policy on Education (2004, 2013) states that:

- The medium of instruction in the primary school shall be the language of the environment for the first three years. During this period, English shall be taught as a subject. $\square$ From the fourth year,

- English shall be progressively used as a medium of instruction and the language of immediate environment and French shall be taught as subjects .

This policy as noted by Lawal (2005) "has been very difficult to implement because of the attitude of the educated class who will rather have their children taught English Language right from the cradle". On the contrary, in the area of education in a proper classroom teaching, pupils in the North Western States of Nigeria prefer to be taught in mother tongue according to the directives of the National Policy Education for easy access and comprehension of pupils who can easily assimilate the English language mode of instruction are those who are conversant with the language in their homes, but in the North Western States even the literate parents prefer to speak the mother tongue to the wards at home. The mother tongue is the only language of communication within the environment, so getting to school to find the teacher teaching in a foreign language cause a kind of disorganization and bewilderment in the pupil thought and consciousness. Pupils in this situation find it very difficult to adjust, learn, or even assimilate the instruction given without an interpreter in his/her other tongue (UNESCO, 2003a) Within the local settings of the Northern people where they assume the Western education as a means of infiltrating their cultural values and religious tenets of the people, children in such an environment went to school under compulsion. Instructing such pupils in a language they do not understand will result in discouraging them, and might not return to school again. Children motivation to learn increases when they find themselves being carried along during the lessons using the language of the environment they become more competent to accomplish school task (UNESCO 2003b)

This is where the parents comes in, they believe that when the child is conversant with the school instruction in their mother tongue and they have acclimatized themselves with the school environment, after a while the English language can then be introduced to the pupils with ease the consequence of the continued preference for English means the displacement and replacement of many Nigerian languages (Bamgbose, 1992).. This portends a great danger to the survival of the indigenous languages. Lawal (2005) highlighted this point when she noted that it is no exaggeration that the use of the mother-tongue is completely banned in some private schools. But the fact remains that the public schools still teach the children in their mother tongue But the Problems is even when they have finished primary school some children still find it difficult to assimilate even at secondary level, subjecting their teachers to teach both in English and Hausa simultaneously.

A number of researches have been carried out in Nigeria which have given empirical data supporting the cognitive advantage of mother-tongue based education. The SIX YEAR PRIMARY PROJECT (University of Ife is a unique study in mothertongue education in Yoruba) the mother tongue of the immediate community of the schools). Adequate attention was at the same time, given to the learning of English as a subject (Badejo, 1990)). This project supports the suggestion made by Lawal (2005) that 
"Nigerian children are better educated first in their mother-tongue"

Even though the language policy of mother tongue education cannot be faulted, it is pertinent to note that pupils prefer the mother tongue due to their environment, while the parents in this part on the country are still indifferent about it. Against the backdrop of the cultural and religious inclination of the Northern Nigeria and the fact that research results have shown that children are naturally endowed to acquire as many languages as possible as long as they are exposed to them before age six. (Lawal, 2005) the prospects of parent encouraging their wards and teachers sandwiching the lessons with Hausa and English at the very beginning is seen as viable. In order not to cut Nigerian students off from their root, the educational system should be truly simultaneously bilingual. (UNESCO 2003) noted that teaching in the mother tongue and the official or national language helps children to obtain better results and also stimulates their cognitive development and capacity to learn. This will equally take care of their affective development which goes hand-in- hand with the cognitive development

\section{Purpose of the Study}

1. To examine the prospects of the use of mother tongue as medium of instruction for pupils in Northwest Nigeria

2. To assess the challenges of the use of mother tongue as a medium of instruction for pupils in Northwest Nigeria

\section{Research Questions}

1. What are the prospects of the use of mother tongue as medium of instruction for pupils in Northwest Nigeria

2. What are the challenges of the use of mother tongue as a medium of instruction for pupils in Northwest Nigeria

\section{Hypothesis}

$\mathbf{H}_{\text {O1: }}$ There is no significant difference in prospects of the use of mother tongue as a medium of instruction for pupils in North West Nigeria based on respondent status.

\section{Methodology}

The method adopted for the study is descriptive survey design This make the descriptive survey design suitable for this study. As observed by Descombe (2003) the notion of survey suggests that the researcher intends to get information from the target respondents. He maintained that surveys are associated with large scale research covering many people. Descriptive analysis of mean and standard deviation was used to answer research questions 1, and 2, while frequency and percentages were used to described the demographic information of the respondents. Oneway analysis of variance was used to test the hypothesis in the study.

\section{Population, Sample, and sampling Technique}

Population of the study include stakeholders' in the society which include parents, guardians, and teachers, involved in childhood education. A total of 907 participated in the study, 113 parents, 30 guardian, and 764 teachers Stratified sampling technique was used to select 3 States from 7 Northwestern states. Which include Katsina, Kebbi, and Sokoto states. Ten (10) metropolitan primary schools were selected from the 3 states using simple random sampling technique.

\section{Instrumentation}

The following instruments was used for the study a four likert scale questionnaire was used to elicit information from the respondents. The validity of the instrument was ascertained using the content validity technique. This approach was use to ensure that the items in the questionnaire correspond with the focus of this study. A pilot study was conducted using one centre which is not part of the study area to ascertain the reliability of the study. Two schools were selected from the Kwara state metropolitan schools using internal consistency based on Crombach alpha, reliability coefficient of 0.78 was established.

\section{Results} Table 1: Demographic Information of the
Respondents

\begin{tabular}{|c|c|c|c|}
\hline $\begin{array}{l}\text { Variabl } \\
\text { e }\end{array}$ & Levels & $\begin{array}{l}\text { Frequenc } \\
\text { y (f) }\end{array}$ & $\begin{array}{r}\text { Percentag } \\
\text { e }(\%)\end{array}$ \\
\hline \multirow{3}{*}{ Sex } & Male & 521 & 57.4 \\
\hline & Female & 386 & 42.6 \\
\hline & Total & 907 & 100.0 \\
\hline \multirow{5}{*}{$\begin{array}{l}\text { Age } \\
\text { (Yrs.) }\end{array}$} & $\begin{array}{l}\text { Below } \\
18 y r s\end{array}$ & 13 & 1.4 \\
\hline & $18-15$ & 273 & 30.1 \\
\hline & $26-35$ & 524 & 57.8 \\
\hline & $36-45$ & 97 & 10.7 \\
\hline & Total & 907 & 100.0 \\
\hline \multirow{4}{*}{ Status } & Parents & 113 & 12.5 \\
\hline & Guardians & 30 & 3.3 \\
\hline & Teachers & 764 & 84.2 \\
\hline & Total & 907 & 100.0 \\
\hline
\end{tabular}

Research Questions 
Research Question 1: What are the prospects of the use of mother tongue as a medium of instruction for pupils in North West Nigeria?

- In order to answer this research question, respondents responses were subjected to a descriptive analysis of mean and standard deviation. In addition, each item was also ranked to determine the degree of the strength attached.The result is presented inTable 2 .

\section{Table 2: Prospects of the Use of Mother Tongue as a Medium of Instruction for Pupils in North West Nigeria}

\begin{tabular}{|c|c|c|c|c|c|}
\hline $\mathbf{S} / \mathbf{N}$ & Prospects of the Use of Mother Tongue & $\mathbf{N}$ & Mean & SD & Rank \\
\hline 1 & $\begin{array}{l}\text { Children are more likely to enroll and succeed in school with } \\
\text { mother tongue }\end{array}$ & 907 & 3.51 & 0.68 & 1 \\
\hline 2 & $\begin{array}{l}\text { Parents are more likely to communicate with teachers and } \\
\text { participate in their children learning }\end{array}$ & 907 & 3.31 & 0.70 & 2 \\
\hline 3 & $\begin{array}{l}\text { Children with less exposure to dominate language stay in school } \\
\text { longer and repeat classes }\end{array}$ & 907 & 3.09 & 0.79 & 11 \\
\hline 4 & $\begin{array}{l}\text { Children expose to mother tongue develop better thinking skills } \\
\text { than others }\end{array}$ & 907 & 3.26 & 0.76 & 7 \\
\hline 5 & Mother tongue helps to achieve the goals of education easily & 907 & 3.31 & 0.74 & 2 \\
\hline 6 & $\begin{array}{l}\text { It is easy to learn with mother tongue both at home and in } \\
\text { school }\end{array}$ & 907 & 3.31 & 0.75 & 2 \\
\hline 7 & $\begin{array}{l}\text { Engaging children with school task with mother tongue leads to } \\
\text { success }\end{array}$ & 907 & 3.27 & 0.75 & $\overline{6}$ \\
\hline 8 & Mother helps the cognitive development of the pupils & 907 & 3.25 & 0.77 & 8 \\
\hline 9 & It is used as an easy means of interaction between pupils & 907 & 3.29 & 0.70 & 5 \\
\hline 10 & $\begin{array}{l}\text { Mother tongue gives the pupils a sense of belonging within } \\
\text { school environment }\end{array}$ & 907 & 3.20 & 0.75 & $\mathbf{1 0}$ \\
\hline 11 & $\begin{array}{l}\text { Mother tongue motivates pupils to participate in the learning } \\
\text { process. }\end{array}$ & 907 & 3.22 & 0.80 & 9 \\
\hline
\end{tabular}

Table 2 shows the prospects of the use of mother tongue as a medium of instruction for pupils as envisaged by parents, guardians and teachers in North West Nigeria. It is shown that "Children are more likely to enroll and succeed in school with mother tongue" was considered the foremost prospect with the highest mean value of 3.51 and SD of 0.68 and ranked first. Prospects such as "Parents are more likely to communicate with teachers and participate in their children learning"; "Mother tongue helps to achieve the goals of education easily" and "It is easy to learn with mother tongue both at home and in school" were ranked second with the same mean value of 3.31 and respective SD value of $0.70,0.74$, and 0.75 . Ranked fifth was the ease of interaction between pupils as a result of the use of mother tongue with mean and SD values of 3.29 and 0.70 respectively while engaging children with school task with mother tongue leads to success was ranked sixth with mean and SD values of 3.27 and 0.75 . Other prospects with their respective mean, SD and ranked include: Children expose to mother tongue develop better thinking skills than others (3.26; 0.76) $7^{\text {th }}$; Mother helps the cognitive development of the pupils $(3.25 ; 0.77) 8^{\text {th }}$; Mother tongue motivates pupils to participate in the learning process $(3.22 ; 0.80) \quad 9^{\text {th }}$; Mother tongue gives the pupils a sense of belonging within school environment $(3.20 ; 0.75) \quad 10^{\text {th }}$ while the least prospect was "Children with less exposure to dominate language stay in school longer and repeat classes" $(3.09 ; 0.79) 11^{\text {th }}$.

Research Question 2: What are the challenges of the use of mother tongue as a medium of instruction for pupils in North West Nigeria?

In order to answer this research question, respondents' responses were subjected to a descriptive analysis of mean and standard deviation. In addition, each item was also ranked to determine the degree of the strength attached. The result is presented in Table in 3. 
Table 3: Challenges of the Use of Mother Tongue as a Medium of Instruction for Pupils in North West Nigeria.

\begin{tabular}{|c|c|c|c|c|c|}
\hline $\mathbf{S} / \mathbf{N}$ & Challenges of the Use of Mother Tongue & $\mathbf{N}$ & Mean & SD & Rank \\
\hline 1 & $\begin{array}{l}\text { It is hard to grasp all the subject contents with the use of mother } \\
\text { tongue as medium of instruction }\end{array}$ & 907 & 2.82 & 0.96 & 6 \\
\hline 2 & $\begin{array}{l}\text { Parents may refrain enrolling their children in school because of the } \\
\text { language of instruction }\end{array}$ & 907 & 2.63 & 0.94 & 13 \\
\hline 3 & Children may not be able to engage successfully in learning tasks & 907 & 2.66 & 0.90 & 11 \\
\hline 4 & $\begin{array}{l}\text { Teachers are feeling overwhelmed with children inability to } \\
\text { participate in learning task using mother tongue }\end{array}$ & 907 & 2.66 & 0.93 & 11 \\
\hline 5 & Children experience school failure with mother tongue & 907 & 2.74 & 0.92 & 10 \\
\hline 6 & $\begin{array}{l}\text { Teachers inability to translate the text book into mother tongue } \\
\text { accurately }\end{array}$ & 907 & 2.78 & 0.93 & 8 \\
\hline 7 & Children difficulty in communication with other children in school & 907 & 2.77 & 0.90 & 9 \\
\hline 8 & $\begin{array}{l}\text { Some children do not succeed with mother tongue language of } \\
\text { instruction }\end{array}$ & 907 & 2.80 & 0.91 & 7 \\
\hline 9 & Pupils fail to be competent in speaking English Language & 907 & 2.90 & 0.87 & 3 \\
\hline 10 & Teachers fail to be English competent and fluent in communication & 907 & 2.87 & 0.87 & 4 \\
\hline 11 & $\begin{array}{l}\text { Pupils find it difficult to relate with other pupils using mother } \\
\text { tongue }\end{array}$ & 907 & 2.87 & 0.89 & 4 \\
\hline 12 & Pupils do not acquire enough vocabulary of the language & 907 & 2.91 & 0.82 & $\mathbf{1}$ \\
\hline 13 & $\begin{array}{l}\text { Mother tongue restricts the pupils from learning the English } \\
\text { language }\end{array}$ & 907 & 2.91 & 0.96 & 1 \\
\hline
\end{tabular}

Table 3 shows the challenges of the use of mother tongue as a medium of instruction for pupils as perceived by parents, guardians and teachers in North West Nigeria. It is shown that "Pupils do not acquire enough vocabulary of the language" and "Mother tongue restricts the pupils from learning the English language" were considered the foremost challenges with the highest mean value of 2.91 and respective SD values of 0.82 and 0.96 . These challenges were ranked first among others. These challenges were closely followed by failure of the pupils to be competent speaking English Language with mean of 2.90, SD of 0.87 and rank of 3 . Challenges such as "Teachers fail to be English competent and fluent in communication" and "Pupils find it difficult to relate with other pupils using mother tongue" were ranked $4^{\text {th }}$ with mean value of 2.87 each and respective SD values of 0.87 and 0.89. "It is hard to grasp all the subject contents with the use of mother tongue as medium of instruction was ranked $6^{\text {th }}$ with mean and SD values of 2.82 and 0.96 respectively while "Some children do not succeed with mother tongue language of instruction" had rank of 7 with mean and SD values of 2.80 and 0.91 respectively. Other challenges with their mean SD, and ranks include: "Teachers inability to translate the text book into mother tongue accurately" $(2.78 ; 0.93) 8^{\text {th }}$; "Children difficulty in communication with other children in school" $(2.77 ; 0.90) 9^{\text {th }}$; "Children experience school failure with mother tongue" $(2.77 ; 0.90) 10^{\text {th }}$; Children may not be able to engage successfully in learning tasks" $(2.66 ; 0.90)$ $11^{\text {th }}$; "Teachers are feeling overwhelmed with children inability to participate in learning task using mother tongue" $(2.66 ; 0.93) 11^{\text {th }}$ and "Parents may refrain enrolling their children in school because of the language of instruction" $(2.63 ; 0.94)$ $13^{\text {th }}$.

$\mathbf{H}_{\text {O1: }}$ There is no significant difference in prospects of the use of mother tongue as a medium of instruction for pupils in North West Nigeria based on respondent status.

In order to test this hypothesis, the mean scores of the respondents were subjected to a One Way Anova using respondents' status as factor variable. The result is presented in Table 4: 
Table 4: One-way analysis of variance test of significant difference in the prospects of the use of mother tongue as a medium of instruction for pupils in North West Nigeria based on respondent status

\begin{tabular}{|l|r|r|r|r|r|}
\hline Source of Variance & $\begin{array}{r}\text { Sum of } \\
\text { Squares }\end{array}$ & df & $\begin{array}{r}\text { Mean } \\
\text { Square }\end{array}$ & F & P \\
\hline Between Groups & 10.347 & 2 & 5.173 & \multirow{2}{*}{.237} & .789 \\
\hline Within Groups & 19743.494 & 904 & 21.840 & .23 & \\
\hline Total & 19753.841 & 906 & & & \\
\hline
\end{tabular}

Table 4 shows a one -way between groups analysis of variance conducted to explore the difference in prospects of the use of mother tongue as a medium of instruction for pupils in North West Nigeria based on respondent status (Parents, guardians and teachers). It can be observed that there was no statistically significant difference in the views of parents, guardians and teachers on the prospects of the use of mother tongue as a medium of instruction for pupils in North West Nigeria because the pvalue is greater than .05 level of significance as determined by one-way ANOVA $(F(2,906)=.237$, $\mathrm{p}=.789$ ). This result concludes that there was no significant difference in the views of parents, guardians and teachers on the prospects of the use of mother tongue as a medium of instruction for pupils in North West Nigeria,

\section{Discussions of Findings}

The result indicated that the prospects of the use of mother tongue as a medium of instruction was considered the foremost prospect with the highest mean value of 3.51 and SD of 0.68 and ranked first. Prospects such as "Parents are more likely to communicate with teachers and participate in their children learning". This findings lends support to the findings of Lawal (2005) which shows that parents are indifferent about their children learning in the mother tongue in school all they are interested in is for them to learn. "Mother tongue helps to achieve the goals of education easily" and "It is easy to learn with mother tongue both at home and in school" were ranked second with the same mean value of 3.31 and respective SD value of 0.70 , 0.74 , and 0.75 , the ease of interaction between pupils as a result of the use of mother tongue with mean and SD values of 3.29 and 0.70 respectively while engaging children with school task with mother tongue leads to success with mean and SD values of 3.27 and 0.75 . This findings contradicts the findings of Benabdi (1980) shows that parents are not always enthusiastic about their children learning in the mother tongue. Other prospects with their respective mean, $\mathrm{SD}$ and ranked include: Children expose to mother tongue develop better thinking skills than others $(3.26 ; 0.76) 7^{\text {th }}$; Mother helps the cognitive development of the pupils $(3.25 ; 0.77) 8^{\text {th }}$; Mother tongue motivates pupils to participate in the learning process $(3.22 ; 0.80) \quad 9^{\text {th }}$; Mother tongue gives the pupils a sense of belonging within school environment $(3.20 ; 0.75)$ This also lends support the findings of Bamgbose (1982), Benabdi (1980), Fafunwa (1990) and Chumbow (1990), maintain that mother tongue education is worth the trouble.

The challenges of the use of mother tongue as a medium of instruction for pupils shows that " Pupils do not acquire enough vocabulary of the language" and "Mother tongue restricts the pupils from learning the English language" were considered the foremost challenges. This supports the findings of (Taiwo, 1976) who observed that absences of mother tongue in primary school teaching could lead to justice and fairness to children who might have had no exposure to English before coming to school. It can be observed that there was no statistically significant difference in the views of parents, guardians and teachers on the prospects of the use of mother tongue as a medium of instruction for pupils in North West Nigeria because the $\mathrm{p}$-value is greater than .05 level of significance as determined by one-way ANOVA $(F(2,906)=.237, \mathrm{p}=.789)$. This supports the findings Awoniyi, (1982), Olagoke, (1979) and Chumbow, ( 1990) observed that it is a way of equalizing educational opportunities for all children especially children in the northern part of the country.

\section{Conclusion and Recommendations}

Based on the findings of this study, which is an indication on how teachers, parents, and other stakeholders relate together and concluded that Mother helps the cognitive development of the pupils, motivates pupils to participate in the learning; and gives the pupils a sense of belonging within school environment. The main purpose of 
learning is for the pupils to assimilate what they are being taught irrespective of the language of instruction. The challenges of mother tongue include: pupils do not acquire enough vocabulary of the language, but rather Mother tongue restricts the pupils from learning the English language and Teachers are feeling overwhelmed with children inability to participate in learning task using mother tongue and as such Parents may refrain enrolling their children in school because of the language of instruction. Since there no significant difference between the views of parents, teachers and other stakeholders on the prospects of the use of mother tongue as a medium of instruction for pupils in North West Nigeria. It is therefore recommended that since the prospects of Mother tongue ate inevitable and its challenges are inherent. Teachers, parents and all stakeholders should be more proactive in discharging their professional functions in teaching of Mother Tongue and the English language currently during lessons.

\section{References}

[1] Badejo, B.R. (1990). "Asymmetrical bilingualism and the national language policy." In Emenanjo, E.N. (ed.) Multilngualism, Minority Languages and Language Policy in Nigeria.

[2] Bamgbose, A. (1982). "Local languages development: policy and practice" In Ikara, B.(ed). Nigerian Languages and Cultural Development. Lagos: The National language Centre.

[3] Bamgbose, A. (1992). Speaking in tongues: implications of multilingualism for language policy in Nigeria. Kaduna: Wemilore Press Ltd.

[4] Benabdi, L.C. (1980). Arabization in Algeria: processes and problems. Unpublished $\mathrm{PhD}$ Dissertation, Indiana University.

[5] Bhatia, K. K. . (2006). Principles' and Practice of Education. Kalyani Publishers fourth revised edition. New Delhi.

[6] Chumbow, B.S. (1990). "The place of mother tongue in the national policy on education." In Emenanjo, E.N. (ed.) Multilingualism, Minority Languages and Language Policy in Nigeria. Agbor: Central Books Ltd. in collaboration with Linguistics Association of Nigeria, 6172.

[7] Descombe, M. (2003). The good research guide for small-scale social research projects.
Maidenhead, Philadelphia Open University Press.

[8] Fafunwa, A.B (1997). "The potentials of utilising African languages for formal education." Paper presented at FESTAC '77 colloquium, Jan., 11-20.

[9] Fafunwa, A.B., Macauley, J. and Sokoya, J.A.F. (eds.) (1989). Education in mother tongue:

The Ife primary education research project. Ibadan: University Press Ltd.

[10] Federal Republic of Nigeria (2004). National Policy on Education (revised). Lagos: NERDC Press Publishers Ltd.

[11] Federal Republic of Nigeria (2013): National Policy on Education. Lagos, NERDC

[12] Lawal, R. A. (2005). Mother tongue education and language problem in Nigeria. A Historical study. Pacific Piblishers. Lagos

[13] Olagoke, D.O. (1979). "The mother tongue and ESL in Nigerian education." In Ubahakwe, E. (ed.). The teaching of English studies. Ibadan: Ibadan University Press.

[14] Pattanayak, D.P. (2003). Mother tongues: The problem of definition and the educational challenge. In Ouane, A. (ed.) Towards a multilingual culture of education. Paris: UNESCO Institute for Education, 39-47.

[15] Taiwo, C.O. (1976). "The mother tongue as a means of promoting equal access to education in Nigeria: problems and solutions." UNESCO Linguistic documentation for developing countries, May 1976.

[16] UNESCO (2003a) Education in a multilingual world, UNESCO Education Position Paper. Paris: UNESCO.

[17] UNESCO (2003b). The mother tongue dilemma. Education Today, No.6, July to September, 4-5.

[18] UNESCO, (2003). Mother tongue dilenmma, Education Today. 6 (1) July to September 4-6. 